\title{
FAKTOR YANG MEMENGARUHI KEPUASAN PELANGGAN DALAM LAYANAN RIDE HAILING DI INDONESIA
}

\author{
FACTORS AFFECTING CUSTOMERS SATISFACTION IN RIDE-HAILING SERVICES IN INDONESIA
}

\author{
Ichsan Salim*)1, Renee Ricardo*), Syaiful Bahri MZ*), dan Tanty Marisa*) \\ *) Magister Manajemen, Program Stratejik Manajemen, Universitas Prasetiya Mulya \\ Jl. R.A.Kartini, Cilandak, Jakarta Selatan, Daerah Khusus Ibukota Jakarta 12430 Indonesia
}

\begin{abstract}
The use of technology in these services has significantly become an important part of people's daily lives. The ease of using ride-hailing services makes the adoption of this service easier to accept and use. The purpose of this study was to investigate the factors influencing customer satisfaction in using online-based ride-hailing services in the sharing economy of business platforms in Indonesia. This study empirically analyzed variable data using non-probability sampling techniques on a questionnaire to 500 sample data from respondents who have used online-based four-wheeled car transportation with a frequency of more than five times a year. The linear regression analysis model is used to examine the effect of 7 variables affecting Indonesia's customer satisfaction. Based on the results, four variables significantly influenced customer satisfaction: tangibility, reliability, responsiveness, and information and communication technology (ICT). The variable that affected but was not significant (marginally significant) was the price, and two variables that did not affect customer satisfaction were assurance and empathy. Thus, ride-hailing service providers need to maintain service quality standards to ensure customer satisfaction. This research is also useful for ride-hailing services to maintain fairness in prices, pay attention to the ease of use of information and communication technology, and maintain customer satisfaction to increase competitive advantage over competitors.
\end{abstract}

Keywords: customer satisfaction, ICT, price, Ride hailing, service quality

\begin{abstract}
Abstrak: Penggunaan teknologi dalam layanan secara signifikan menjadi bagian penting dalam kehidupan sehari-hari masyarakat. Dengan kemudahan dalam penggunaan layanan ride hailing, membuat adopsi layanan ini lebih mudah diterima dan digunakan. Penelitian ini dibuat dengan tujuan menginvestigasi variable-variable yang secara signifikan memengaruhi kepuasan pelanggan (customer satisfaction) dalam penggunaan layanan ride hailing berbasis online dalam sharing economy platform bisnis di Indonesia. Penelitian ini secara empiris menganalisis variable data dengan menggunakan teknik non-probability sampling atas kuesioner kepada 500 sample data dari responden yang telah menggunakan transportasi kendaraan bermotor roda empat berbasis online dengan frekuensi lebih dari lima kali dalam satu tahun. Model analisis regresi linear digunakan untuk meneliti pengaruh tujuh variabel yang memengaruhi customer satisfaction di Indonesia. Dari hasil penelitian ditemukan empat variabel yang memengaruhi secara signifikan terhadap customer satisfaction yaitu tangibility, reliability, responsiveness dan information and communication technology (ICT), satu variabel yang memengaruhi namun tidak signifikan (marginally significant) yaitu harga (price) dan dua variabel yang tidak memengaruhi kepuasan konsumen yaitu assurance dan emphaty. Dengan demikian, sangat penting bagi penyedia jasa ride hailing untuk mempertahankan standar kualitas layanan untuk memastikan kepuasan pelanggan. Penelitian ini juga bermanfaat bagi layanan ride hailing untuk menjaga kewajaran harga, tetap memperhatikan faktor kemudahan penggunaan teknologi informasi dan komunikasi, serta mempertahankan customer satisfaction untuk meningkatkan keunggulan kompetitif dibandingkan pesaing.
\end{abstract}

Kata kunci: harga, ICT , kepuasan pelanggan, ride hailing, service quality

\footnotetext{
${ }^{1}$ Alamat Korespondensi:

Email: Ichsan.salim@student.pmbs.ac.id
} 


\section{PENDAHULUAN}

Perkembangan teknologi saat ini sudah sangat pesat, penggunaan teknologi telah menjadi bagian penting untuk memudahkan kehidupan sehari-hari (McCarthy dan Wright, 2018), salah satunya di bidang transportasi yaitu layanan ride hailing. Layanan ride hailing adalah layanan transportasi menggunakan platform online, sepertiaplikasiyangmenghubungkan antarapenumpang dengan pengemudi, penumpang menentukan lokasi penjemputan dan tujuannya serta dengan tarif yang sudah pasti, dimana layanan ini di kelola oleh pihak ketiga yaitu perusahaan jaringan transportasi (Pham et al. 2017). Layanan ini secara signifikan dapat meningkatkan efisiensi penumpang dalam memesan transportasi online dan menurunkan waktu tunggu serta tingkat kekosongan transportasi online jika dibandingkan dengan transportasi tradisional (Feng et al. 2017). Kemudahan dan manfaat dari layanan ride hailing, layanan ini mudah untuk diterima di seluruh dunia (Clewlow dan Mishra, 2017).

Di Indonesia sendiri layanan ride hailing mulai dikenal pada tahun 2015 dan semakin berkembang hingga saat ini (Christina et al. 2018). Dimulai dengan berdirinya Go-Jek sebagai perusahaan lokal pertama yang menyediakan layanan ride hailing pada tahun 2011 dan di ikuti oleh Grab dan Uber pada tahun 2014 (Prabowo, 2018). Untuk saat ini hanya ada dua perusahaan yang beroperasi di Indonesia yaitu Go-Jek dan Grab, setelah Uber tidak lagi beroperasi, dimana Grab mengakuisisi seluruh aset Uber di kawasan Asia Tenggara di pertengahan tahun 2018 (Forbes, 2018). Saat ini Grab menjadi pemimpin dalam layanan ride hailing di Indonesia dengan pangsa pasar sebesar 64\% (Hodgson, 2019).

Dimasa lalu, industri transportasi konvensional selalu menekankan keunggulan layanan terutama pada kualitas layanan baik itu kualitas teknis dan kualitas fungsional, seperti hanya dari kondisi fisik angkutan, kenyamanan, keamanan dan keselamatan (Ha et al. 2019; Noor, Nasrudin, dan Foo, 2014). Hal ini menunjukkan bahwa ketika pelanggan sudah mendapatkan kualitas teknis dan kualitas fungsional yang baik, mereka sudah merasa puas meskipun dengan harga yang tinggi (Munnukka, 2005; Tam, 2004).
Kepuasaan pelanggan semakin kompleks karena harga dinilai sebagai penentu utama dari kepuasaan pelanggan (Herrmann et al. 2007). Pelanggan mulai sadar akan ketidaksesuaian harga dan cara perusahaan memastikan harga layanan sudah sesuai untuk pelanggan mereka (Herrmann et al. 2007; Lombart dan Louis, 2014). Namun, saat ini dengan adanya teknologi di bidang transportasi kepuasaan pelanggan juga sangat dipengaruhi oleh information and communication technology (ICT) (Suhami et al. 2018). Dengan adanya $I C T$, transportasi online menjadi jauh lebih efisien dan luas dengan kemampuan aplikasi seluler dan komunikasi internet yang bisa memberikan informasi data terkini bagi calon penumpang (Siddiqi dan Buliung, 2013). Dengan demikian ada mata rantai yang hilang jika perusahaan hanya mengandalkan kualitas layanan atau harga atau ICT dalam industri ride hailing untuk memengaruhi customer satisfaction mereka.

Oleh karena itu, tantangan dalam penelitian ini adalah untuk menunjukkan apakah kualitas layanan, harga dan ICT akan menambah nilai bagi pelanggan yang berdampak pada kepuasaan mereka. Kepuasaan pelanggan adalah masalah utama di pasar yang sangat kompetitif saat ini (Poliakov, 2010). Penting bagi perusahaan untuk meningkatkan kualitas layanan, produk untuk dapat bersaing di pasar yang kompetitif (O’Loughlin dan Coenders, 2002).

Para peneliti dan akademisi hingga saat ini banyak berkontribusi terhadap customer satisfaction di industri ride hailing (Balachandran dan Hamzah, 2017; Christina et al. 2018; Feng et al. 2017; Man et al. 2019; Mayanda, Wijayanto, dan Muflikhati, 2018) penelitian yang sangat terbatas hanya menilai faktorfaktor yang mengukur dampak kualitas layanan pada kepuasaan pelanggan, penelitian ini menganalisa secara keseluruhan dampak kualitas layanan, harga dan ICT terhadap kepuasaan pelanggan dalam industri ride hailing di Indonesia. Oleh karena itu, penelitian ini bertujuan untuk menginvestigasi tujuh faktor yang memengaruhi customer satisfaction dalam penggunaan layanan ride hailing berbasis online dalam sharing economy platform bisnis di Indonesia. Hasil dari kepuasaan pelanggan diharapkan dapat memberikan umpan balik untuk meningkatkan kualitas layanan serta dapat menemukan solusi dan inovasi untuk perusahaan layanan ride hailing di Indonesia sehingga mereka dapat memberikan kepuasaan yang sesuai dengan yang di harapkan pelanggan. 
Tujuan penelitian ini adalah menginvestigasi faktor yang memengaruhi kepuasan pelanggan (customer satisfaction) dalam penggunaan layanan ride hailing berbasis online dalam sharing economy platform bisnis di Indonesia. Variabel bebas yang digunakan yaitu servqual (Parasuraman, Zeithaml, dan Berry, 1988), harga, ICT dan pengaruhnya dengan customer satisfaction. Ruang lingkup penelitian ini hanya mencakup pada layanan ride hailing kendaraan bermotor roda empat, tidak melibatkan kendaraan bermotor roda dua.

\section{METODE PENELITIAN}

Penelitian ini menggunakan metode kuantitatif, yang memiliki karakteristik sebagai berikut: (1) mempelajari pengaruh antar variabel, yang diukur secara numerik dan dianalisis menggunakan teknik statistik; (2) menggunakan teknik pengumpulan data tunggal seperti kuesioner (Saunders et al. 2009). Penelitian ini juga menggunakan teknik non-probability sampling, dengan model volunteer dan purposive sampling (Saunders et al. 2009). Kriteria yang dimaksud adalah subyek sudah pernah menggunakan transportasi kendaraan bermotor roda empat berbasis online dan subyek sudah menggunakan jasa tersebut dengan frekuensi lebih dari lima kali dalam kurun waktu satu tahun terakhir.

Pengambilan data penelitian dikumpulkan dari responden yang didapat dari beberapa sumber yaitu daftar individual kontak peneliti, beberapa komunitas dan aplikasi pesan ponsel cerdas seperti WhatsApp, Telegram dan Line. Sumber lain dikumpulkan melalui media sosial seperti Instagram dan LinkedIn. Domisili responden tersebar di beberapa kota besar di seluruh Indonesia.

Kuesioner dibuat dalam bentuk formulir digital, yang dibuat menggunakan Google Form, tautannya disebarkan melalui email, media komunikasi WhatsApp dan media sosial Instagram dan LinkedIn. Peneliti menerima kembali kuesioner yang terisi sejumlah total 546 kuesioner. Kemudian semua responden diseleksi apakah memenuhi kriteria tersebut di atas, dan didapatkan 500 sampel data atau 91,6\% yang dapat dianalisis. Periode proses pengambilan data dimulai sejak bulan Februari 2020 hingga April 2020.
Kuesioner tersebut mengadopsi dari penelitian (Man et al. 2019; Suhami et al. 2018) yang terdiri dari 31 pertanyaan tentang persepsi pengguna layanan yang mencerminkan 8 variabel penelitian ini. Skala Likert 5 tingkat untuk mengukur pengaruh aspek service quality, yang terdiri dari tangibility (tampilan fisik kendaraan bermotor roda empat dan pengemudi), reliability (keandalan pelayanan yang diberikan), responsiveness (kemampuan menanggapi kebutuhan), assurance (jaminan pelayanan) dan empathy (perilaku pengemudi seperti sikap hormat, sopan dan menyenangkan), price (aspek kewajaran harga di mata konsumen dibandingkan dengan harga yang ditawarkan kompetitor pada kategori yang sama) dan information \& communication technology (ICT) (kemudahan penggunaan aplikasi), terhadap customer satisfaction (kepuasan pelanggan dalam menggunakan layanan secara keseluruhan).

Proses analisis sampel data menggunakan piranti lunak IBM SPSS Statistics 26. Diawali dengan uji kecukupan sampel untuk factor analysis menggunakan uji KaiserMeyer-Olkin and Bartlett's Test of Sphericity. Kemudian dilanjutkan dengan analisis validitas menggunakan uji Eigen Values per variabel (Burns dan Burns, 2008). Kemudian dilakukan analisis reliabilitas untuk menguji seberapa konsisten pengukuran yang dilakukan pada tiap variabel, dengan menggunakan uji Cronbach's Alpha (Burns dan Burns, 2008).

Dari hasil diatas, maka analisis dapat dilanjutkan dengan menggunakan metode regresi linear. Diawali dengan uji $\mathrm{F}$ untuk melihat nilai signifikansi sebagai syarat agar dapat memaknai nilai koefisien determinasi atau Adjusted $R$ Square yang seberapa besar kontribusi independen variabel secara simultan dalam memengaruhi dependen variabel (Burns dan Burns, 2008; Cooper dan Schindler, 2014; Saunders et al. 2009). Berikutnya peneliti menentukan Standardized Coefficients Beta untuk melihat bagaimana masingmasing independen variabel memengaruhi variabel dependennya. Apabila nilainya positif, dapat diartikan independen variabel tersebut memengaruhi langsung dengan dependen variabelnya. Namun apabila nilainya negatif, maka variabel independen tidak memengaruhi variabel dependen (Burns dan Burns, 2008).

Dengan uji $P$-Value, peneliti menguji nilai signifikansi (Sig.) dari masing-masing variabel independen dan pengaruh masing-masing independen variabel terhadap dependen variabel (H1 hingga H7). Apabila nilai Signifikansi lebih kecil dari 0,05 maka independen 
variabel tersebut diartikan mempunyai pengaruh yang signifikan terhadap dependen variabelnya (Burns dan Burns, 2008; Saunders et al. 2009).Beberapa hipotesis telah ditentukan untuk melihat pengaruh dari masing masing variabel bebas terhadap customer satisfaction pada industri ride hailing berbasis online di Indonesia adalah sebagai berikut:

H1: Ada pengaruh signifikan antara tangibility dengan customer satisfaction pada ride hailing berbasis online di Indonesia.

$\mathrm{H} 2$ : Ada pengaruh signifikan antara reliability dengan customer satisfaction pada ride hailing berbasis online di Indonesia.

H3: Ada pengaruh signifikan antara responsiveness dengan customer satisfaction pada ride hailing berbasis online di Indonesia.

H4: Ada pengaruh signifikan antara assurance dengan customer satisfaction pada ride hailing berbasis online di Indonesia.

H5: Ada pengaruh signifikan antara empathy dengan customer satisfaction pada ride hailing berbasis online di Indonesia.

H6: Ada pengaruh signifikan antara price dengan customer satisfaction pada ride hailing berbasis online di Indonesia.

H7: Ada pengaruh signifikan antara ICT dengan customer satisfaction pada ride hailing berbasis online di Indonesia.

Pada Gambar 1 terlihat bahwa penelitian ini menunjukkan hubungan antara independen variable customer satisfaction dan dependen variabel yaitu servqual serta keterjangkauan harga dan ICT. Variabel servqual terdiri dari tangibility, reliability, responsiveness, assurance dan empathy (Parasuraman et al. 1988). Analisis diawali dengan mengetahui ada tidaknya pengaruh yang signifikan dari masing-masing variabel dependen terhadap customer satisfaction. Hasil dari analisis dapat menjadi masukan bagi penyedia layanan ride hailing di Indonesia.

\section{HASIL}

Pada penelitian ini, didapatkan sejumlah responden dengan profil demografi yang cukup beragam. Pembagian kategori dilakukan berdasarkan jenis kelamin, rentang usia, pendapatan dan profesi. Kategori rentang usia dibagi berdasarkan kelompok demografi generasi. Pendapatan dibagi menurut kelompok pendapatan per kapita versi Bank Dunia tahun 2020, yaitu Lower Middle Income, Upper Middle Income dan High Income (Serajuddin dan Hamadeh, 2020). Profesi dibagi berdasarkan kelompok mayoritas. Profil demografi yang diperoleh disajikan di Tabel 1.

Explanatory factor analysis tercermin dari 31 pertanyaan dalam kuesioner. Dari uji kecukupan sampel didapatkan hasil dari Kaiser-Meyer-Olkin (KMO) adalah 0,959 dengan nilai signifikansi (Sig.) $=0,000$. Maka diartikan sampel sudah sesuai dengan factor analysis, adanya pengaruh antar variabel dan sekaligus layak untuk diproses lebih lanjut. Analisis validitas menggunakan uji Eigen Values per variabel. Tabel 2 menampilkan kompilasi hasil dari analisis validitas dan analisis reliabilitas dari masing-masing variabel konstruk adalah lebih dari 1 dengan range antara 2,059 - 3,430,maka diartikan semua variabel adalah valid.

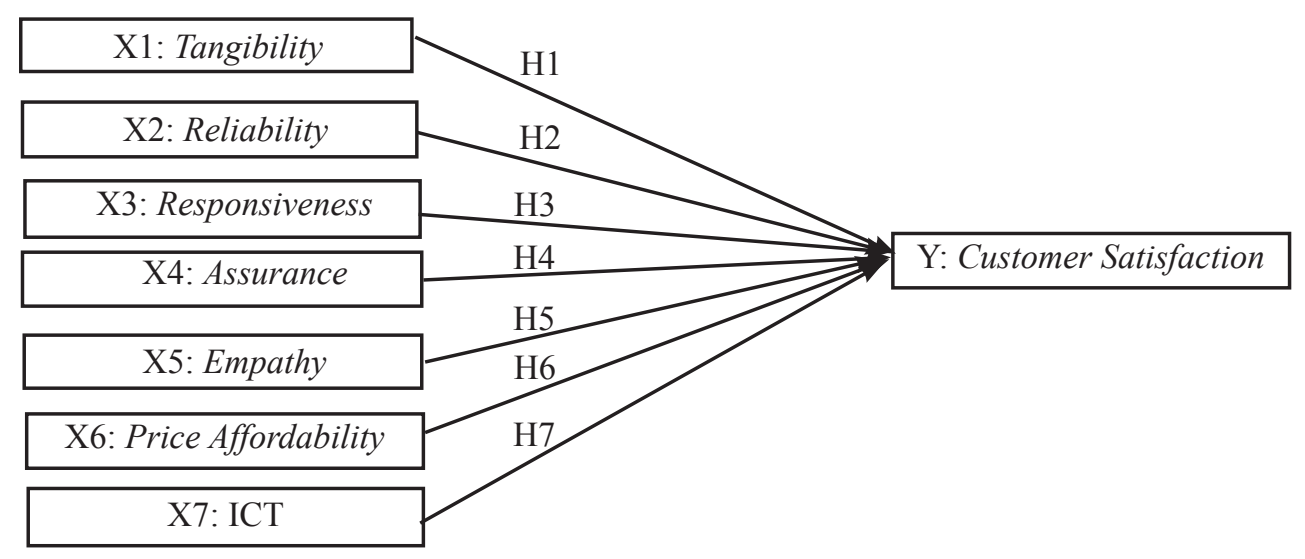

Gambar 1. Kerangka pemikiran penelitian 
Tabel 1. Profil Demografi

\begin{tabular}{llc}
\hline Kategori & Keterangan & Persentase (\%) \\
\hline Jenis kelamin & Perempuan & 64,3 \\
Rentang usia & Laki-laki & 35,7 \\
& $<23$ tahun & 11,2 \\
& $24<\mathrm{x}<39$ tahun & 69,7 \\
& $40<\mathrm{x}<55$ tahun & 17,7 \\
Pendapatan & $>56$ tahun & 1,4 \\
& $<5$ juta & 31,4 \\
Profesi & $5<\mathrm{x}<15$ juta & 46,5 \\
& $>15$ juta & 22,1 \\
& Pegawai swasta & 55,8 \\
& Pengusaha dan wiraswasta & 11,1 \\
& Pegawai negeri sipil & 5,4 \\
\hline
\end{tabular}

Tabel 2. Kompilasi hasil dari analisis validitas dan analisis reliabilitas dari masing-masing variabel

\begin{tabular}{|c|c|c|c|c|}
\hline Construct & Item & Loadings & Eigenvalues & Cronbach's Alpha \\
\hline \multirow[t]{6}{*}{ Customer Satisfaction } & no01_CS1 & 0,856 & 3,43 & 0,842 \\
\hline & no02_CS2 & 0,801 & & \\
\hline & no03_CS3 & 0,732 & & \\
\hline & no04_CS4 & 0,738 & & \\
\hline & no05_CS5 & 0,754 & & \\
\hline & no06_CS6 & 0,637 & & \\
\hline \multirow[t]{3}{*}{ Tangibility } & no07_TA1 & 0,866 & 2,059 & 0,77 \\
\hline & no08_TA2 & 0,751 & & \\
\hline & no09_TA3 & 0,863 & & \\
\hline \multirow[t]{4}{*}{ Realibility } & no10_RA1 & 0,752 & 2,581 & 0,816 \\
\hline & no11_RA2 & 0,800 & & \\
\hline & no12_RA3 & 0,829 & & \\
\hline & no13_RA4 & 0,829 & & \\
\hline \multirow[t]{4}{*}{ Responsiveness } & no14_RS1 & 0,799 & 2,589 & 0,817 \\
\hline & no15_RS2 & 0,827 & & \\
\hline & no16_RS3 & 0,801 & & \\
\hline & no17_RS4 & 0,791 & & \\
\hline \multirow[t]{4}{*}{ Assurance } & no18_AS1 & 0,806 & 2,825 & 0,861 \\
\hline & no19_AS2 & 0,843 & & \\
\hline & no20_AS3 & 0,874 & & \\
\hline & no21_AS4 & 0,836 & & \\
\hline \multirow[t]{3}{*}{ Emphaty } & no22_EM1 & 0,839 & 2,135 & 0,792 \\
\hline & no23_EM2 & 0,814 & & \\
\hline & no24_EM3 & 0,876 & & \\
\hline \multirow[t]{4}{*}{ Price } & no25_PR1 & 0,771 & 2,186 & 0,717 \\
\hline & no26_PR2 & 0,712 & & \\
\hline & no27_PR3 & 0,725 & & \\
\hline & no28_PR4 & 0,747 & & \\
\hline \multirow[t]{3}{*}{$I C T$} & no29_IT1 & 0,856 & 2,307 & 0,849 \\
\hline & no30_IT2 & 0,901 & & \\
\hline & no31_IT3 & 0,874 & & \\
\hline
\end{tabular}


Analisis Reliabilitas dilakukan dengan menggunakan uji Cronbach's Alpha. Hasil analisis yang diperoleh adalah semua nilai Cronbach's Alpha dari tiap variabel adalah diatas 0,7 dengan range antara 0,717 - 0,849. Dari range tersebut dapat diartikan semua variabel sudah reliabel atau pengukurannya konsisten dan cocok digunakan dalam survey.

Proses dilanjutkan dengan analisis deskriptif menggunakan metode regresi linear. Proses ini diawali dengan uji $\mathrm{F}$ dengan nilai signifikansi (Sig.) $=0,000$ artinya syarat agar dapat memaknai nilai koefisien determinasi ( $R$ Square) sudah terpenuhi. $R$ Square menunjukkan seberapa besar kontribusi independen variabel secara simultan dalam memengaruhi dependen variabel. Nilai adjusted $R$ Square ditampilkan dalam Gambar 2.

Koefisien determinasi ( $R$ Square) sebesar 0,613 dan tingkat Adjusted R Square untuk Customer Satisfaction sebesar 0,607 , mengindikasikan service quality, price dan ICT memiliki kontribusi pengaruh signifikan terhadap customersatisfaction sebesar $60,7 \%$, sementara sisanya dipengaruhi oleh faktor lain diluar penelitian ini. Tidak semua variabel independen memengaruhi secara signifikan terhadap variabel dependen dalam penelitian ini. Pengaruh antara 1 dependen variabel customer satisfaction dengan 7 faktor independen lainnya dalam penelitian ini adalah sebagai berikut:

Hasil pengukuran Standardized Coefficients Beta menunjukkan variabel yang memengaruhi langsung tingkat customer satisfaction adalah 5 varibel (tangibility 0,168 , reliability 0,393 , responsiveness 0,180, price 0,071 dan ICT 0,191), sementara variabel assurance dan empathy tidak memengaruhi customer satisfaction. Standardized Coefficients Beta assurance dan empathy menunjukkan masing-masing sebesar $(-0,061$ dan $-0,035)$.

Nilai signifikansi (P-Value) untuk variabel tangibility, reliability, responsiveness, ICT sebesar masing - masing $0,000,0,000,0,001$ dan 0,000 , artinya dalam penelitian ini secara empiris memengaruhi customer satisfaction secara signifikan. Dengan demikian H1, H2, H3 dan H7 diterima.

Pengaruh tangibility dan reliability berpengaruh signifikan terhadap kepuasan konsumen sesuai dengan penelitian (Khuong dan Dai, 2016; Man et al. 2019; Mudenda dan Guga, 2017; Rida Khurshid et al. 2012). Variabel responsiveness terhadap industri jasa membuktikan bahwa respon kepada pelanggan yang tinggi memiliki efek positif pada kepuasan, sesuai dengan penelitian (Rahhal, 2015; Uyoga, 2018).

Sementara variabel assurance, empathy dan price lebih besar dari level 5\%, dengan assurance $=0,302$, empathy $=0,479$ dan price $=0,1$. Hal ini dapat diartikan variabel assurance dan empathy tidak secara signifikan memengaruhi customer satisfaction dalam penelitian ini. Oleh karena itu pada level 5\%, H4 dan H5 ditolak. Pengaruh assurance yang tidak secara signifikan memberi dampak pada customer satisfaction sesuai dengan beberapa penelitian sebelumnya yaitu (Minh et al. 2015). Faktor empathy tidak memiliki pengaruh yang positif pada kepuasan konsumen (Suharto dan Sulistiyono, 2015). Empathy adalah perhatian individual dan kepedulian yang diberikan penyedia layanan kepada pelanggannya (Kim et al. 2003), penelitian ini mengukur empati dengan kualitas layanan kepada pelanggan.

\begin{tabular}{|c|c|c|}
\hline X1: Tangibility & $1 . \beta=0.168 ; p=0.000(p<0.01)$ & \multirow{7}{*}{$\begin{array}{l}\text { Y: Customer } \\
\text { Satisfaction }\end{array}$} \\
\hline $\mathrm{X} 2$ : Reliability & 2. $\beta=0.393 ; p=0.000(p<0.01)$ & \\
\hline X3: Responsiveness & 3. $\beta=0.180 ; p=0.001(p<0.01)$ & \\
\hline X4: Assurance & 4. $\beta=-0.061 ; p=0.302(p<0.01)$ & \\
\hline X5: Empathy & 5. $\beta=-0.035 ; p=0.479(p<0.01)$ & \\
\hline X6: Price Affordability & $6 . \beta=0.071 ; p=0.100(p<0.01)$ & \\
\hline X7: ICT & 7. $\beta=0.191 ; p=0.000(p<0.01)$ & \\
\hline
\end{tabular}

Gambar 2. Nilai Adjusted R Square 
Dalam jurnal (Barrera et al. 2016), secara spesifik menjelaskan mengenai transaksi online dengan penekanan pada aplikasi layanan mobile (aspek ICT) dan peningkatan respon pengguna. Faktor price dapat di anggap memiliki pengaruh positif namun signifikan secara marginal terhadap customer satisfaction di level 10\%. Diartikan H6 diterima pada level 10\%.

Hubungan kewajaran harga (price) berpengaruh positif terhadap customer satisfaction namun tidak secara signifikan. Pengguna layanan ride hailing secara online hanya melihat harga layanan wajar apabila harga yang ditawarkan lebih murah dari kompetitor lain, relatif wajar dibandingkan harga layanan sebelumnya, dan apabila perusahaan penyedia ride hailing online tidak mengambil banyak keuntungan dari transaksi layanan seperti dalam penelitian (Hamenda, 2018; Martín-Ruiz dan Rondán-Cataluña, 2008; Martin et al. 2009).

\section{Implikasi Manajerial}

Hasil analisis yang telah dilakukan mengenai faktorfaktor yang memengaruhi kepuasan pelanggan diharapkan dapat memberikan nilai tambah bagi perusahaan penyedia layanan ride hailing di Indonesia. Pelakuusaharidehailing harusmemperhatikan beberapa faktor utama dan memengaruhi langsung terhadap tingkat kepuasan oleh pelanggan, yaitu tangibility, reliability, responsiveness, dan ICT. Keempat faktor ini harus dipenuhi tanpa mengesampingkan tiga faktor lain yang harus dipenuhi sebagai standar minimal kepuasan pelanggan yaitu price, assurance dan emphaty.

Tangibility merupakan hasil dominan yang mencerminkan berbagai fasilitas yang dapat dilihat dan digunakan perusahaan dalam upaya memenuhi kepuasan pelanggan mencakup keadaan fisik kendaraan, mitra pengemudi dan aplikasi yang informatif. Reliability merupakan keakuratan dari kemampuan dalam memberikan layanan dengan cepat dan dapat diandalkan, mencakup faktor keandalan perusahaan penyedia layanan ride hailing, aspek keamanan transportasi online, tarif yang dapat dipercaya dan pemberian layanan sesuai yang dijanjikan. Responsiveness merupakan sikap tanggap, mau mendengarkan dan merespon pelanggan dalam upaya meningkatkan kepuasan pelanggan, faktor ini tergantung dari kemampuan memberi informasi tentang keterlambatan layanan, rute alternatif, komunikasi yang jelas dari mitra pengemudi dan layanan tepat waktu sesuai yang tertera di aplikasi.
ICT merupakan kemampuan menyajikan aplikasi yang mudah digunakan, dengan desain yang menarik dan menyampaikan informasi yang memadai. Empat variabel tersebut memengaruhi langsung terhadap tingkat customer satisfaction secara signifikan diangka $60.7 \%$. Hal ini sejalan dengan Ipenelitian (Khuong dan Dai, 2016; Man et al. 2019; Mudenda dan Guga, 2017; Rida Khurshid et al. 2012) mengenai tangibility dan reliability dan juga penelitian (Rahhal, 2015; Uyoga, 2018) mengenai responsiveness.

Faktor price memiliki pengaruh positif, tetapi signifikan secara marginal terhadap customer satisfaction di level $10 \%$. Hal ini sejalan dengan penelitian (Hamenda, 2018; Martín-Ruiz dan Rondán-Cataluña, 2008; Martin et al. 2009) mengenai kewajaran harga. Faktor price ditentukan oleh berbagai macam promosi dan diskon yang diberikan oleh penyedia jasa ride hailing dan kemampuan memberikan harga yang lebih rendah dari taksi konvensional.

Hasil penelitian menunjukkan variabel assurance dan empathy tidak memengaruhi customer satisfaction. Hal-hal terkait kemampuan pengemudi untuk menjemput dan mengantar penumpang dengan tepat waktu merupakan hal wajar yang harus dimiliki mitra pengemudi. Adanya faktor ini menghilangkan ketidakpuasan pelanggan namun keberadaannya tidak akan menambah kepuasan pelanggan.

\section{KESIMPULAN DAN SARAN}

\section{Kesimpulan}

Kesimpulan yang didapat dari penelitian ini, tangibility, reliability, responsiveness, dan ICT berpengaruh langsung terhadap tingkat customer satisfaction secara signifikan. Sementara price hanya berpengaruh pada level 10\%, sedangkan variabel assurance dan empathy tidak memengaruhi kepuasan pelanggan. Dari hasil ini bisa dilihat bahwa ternyata harga bukan faktor penentu dari kepuasan pelanggan. Kemudahan serta kelebihan dari aplikasi dalam ICT lebih menentukan dari harga.

Dengan demikian sangat penting bagi penyedia jasa ride hailing untuk mempertahankan standar kualitas layanan yang tinggi, teknologi platform yang user friendly serta harga yang bersaing untuk memastikan kepuasan pelanggan. Salah satu cara yang dapat dilakukan adalah dengan melakukan survey kepada para 
customer serta melakukan competitor analysis untuk mengetahui kekurangan serta kelemahan layanan serta kewajaran harga agar dapat meningkatkan keunggulan kompetitif dibandingkan dengan pesaing dan tumbuh menjadi yang terbesar di industri.

\section{Saran}

Mengacu pada hasil penelitian ini, hal-hal yang dapat dipertahankan dan ditingkatkan oleh penyedia layanan ride hailing di Indonesia adalah dengan cara menetapkan standar kerapian mitra pengemudi dan kebersihan kendaraan yang secara konsisten dievaluasi secara berkala. Aspek keandalan juga menjadi ukuran pelanggan terkait kepuasan maka penyedia layanan ride hailing wajib mempertahankannya dengan cara menanggapi secara responsif komentar pelanggan baik positif maupun negatif serta menindaklanjuti semua keluhan pelanggan sampai selesai. Aplikasi ride hailing di ponsel pintar merupakan pintu masuk bagi pelanggan dalam menggunakan layanan ini, oleh karena itu penyedia layanan ride hailing wajib memperhatikan aspek kemudahan dalam penggunaan aplikasi dengan pemberian informasi yang jelas, memadai, mudah digunakan dengan desain menarik. Faktor ICT tetap harus bisa diakses dengan cepat, penyedia layanan harus menyediakan umpan balik terkait masukan pelanggan atas responsifitas penyediaan layanan via aplikasi. Ruang lingkup dalam penelitian ini memberikan arahan untuk penelitian selanjutnya salah satunya adalah alasan hubungan keterkaitan faktor assurance dan empathy tidak memengaruhi customer satisfaction di Indonesia.

\section{DAFTAR PUSTAKA}

Balachandran I, Hamzah IB. 2017. The influence of customer satisfaction on ride-sharing services in Malaysia. International Journal of Accounting \& Business Management 5(2): 184-96.

Barrera RB, Antonio NG, Borja SA. 2016. Exploring the role of the type of service encounter in internet shopping. International Journal of Business and Society 17(2): 201-20. https://doi.org/10.33736/ ijbs.521.2016.

Burns RB, Richard A. Burns. 2008. Business research methods and statistics using SPSS. London: Sage Publications.

Christina H, Usep S, Mohamad R. 2018. Analisis penerimaan dan penggunaan teknologi ojek online dengan TAM. Jurnal Pendidikan Ekonomi Dan Bisnis (JPEB) 6(1): 34-44. https://doi. org/10.21009/JPEB.006.1.4.

Clewlow, Regina R, Gouri SM. 2017. Disruptive transportation: The adoption, utilization, and impacts of ride-hailing in the United States. Institute of Transportation Studies, University of California, Davis 44(6): 1307-23. https://doi. org/10.1016/j.jtrangeo.2014.04.017.

Cooper DR, Pamela SS. 2014. Business research methods business research methods 12 th Edition.

Feng G, Guangwen K, Zizhuo W. 2017. We are on the way: Analysis of on-demand ride-hailing systems. SSRN Electronic Journal 1-51. https:// doi.org/10.2139/ssm.2960991.

Forbes. 2018. Grab officially takes control of uber's Southeast Asia operations. Forbes. com.https://www. forbes.com/sites/ daniellekeetonolsen/2018/03/26/grabofficially-takes-control-of-ubers-southeast-asiaoperations/\#caf73a06c574 [7 Apr 2020].

Ha ST. et al. 2019. Factors affecting satisfaction and loyalty in public transport using partial least squares structural equation modeling (PLSSEM). International Journal of Innovative Technology and Exploring Engineering 8(12): 569-75. https://doi.org/10.35940/ijitee. L3453.1081219.

Hamenda A. 2018. An integrated model of service quality, price fairness, ethical practice and customer perceived values for customer satisfaction of sharing economy platform. International Journal of Business and Society 19(3): 709-24.

Herrmann A, Lan X, Monroe BK, Frank H. 2007. The influence of price fairness on customer satisfaction: An empirical test in the context of automobile purchases. Journal of Product and Brand Management 16(1): 49-58. https://doi. org/10.1108/10610420710731151.

Hodgson J. 2019. APAC ride-hailing apps get supercharged. ABIresearch. https://www. abiresearch.com/blogs/2019/09/18/ride-hailingapps-get-supercharged/ [April 7, 2020].

Khuong MN, Ngo QD. 2016. The factors affecting customer satisfaction and customer loyalty A Study of Local Taxi Companies in Ho Chi Minh City, Vietnam. International Journal of Innovation, Management and Technology 7(5): 228-33. 
Kim J, Euiho S, Hyunseok H. 2003. A model for evaluating the effectiveness of crm using the balanced scorecard. Journal of Interactive Marketing 17(2): 5-19. https://doi.org/10.1002/ dir.10051.

Lombart C, Didier L. 2014. A study of the impact of corporate social responsibility and price image on retailer personality and consumers' reactions (satisfaction, trust and loyalty to the retailer). Journal of Retailing and Consumer Services 21(4): 630-42. http://dx.doi.org/10.1016/j. jretconser.2013.11.009.

Man CK et al. 2019. Evaluation of service quality dimensions towards customer's satisfaction of ride-hailing services in Kuala Lumpur, Malaysia. International Journal of Recent Technology and Engineering 7(5): 102-9.

Martín-Ruiz D, Francisco JR. 2008. The nature and consequences of price unfairness in services: A comparison to tangible goods. International Journal of Service Industry Management 19(3): 325-52. https://doi. org/10.1108/09564230810875002.

Martin WC, Nicole P, Jason EL. 2009. Price fairness perceptions and customer loyalty in a retail context. Journal of Business Research 62(6): 588-93. http://dx.doi.org/10.1016/j. jbusres.2008.05.017.

Mayanda L, Hari W, Istiqlaliyah M. 2018. Factors affecting satisfaction and loyalty of online taximotor partners. Indonesian Journal of Business and Entrepreneurship 4(2): 207-16. https://doi. org/10.17358/ijbe.4.2.207.

McCarthy J, Peter W. 2018. Living with technology. Technology as Experience: 1-5.

Minh NH et al. 2015. Service quality and customer satisfaction: A case study of hotel industry in Vietnam. Asian Social Science 11(10): 73-85. https://doi.org/10.5539/ass.v11n10p73.

Mudenda C, Guga D. 2017. An assessment of the relationship between service quality and customer satisfaction-a case of a public passenger road transportation company in Zambia. International Review of Management and Business Research 6(2): 2306-9007.

Munnukka J. 2005. Dynamics of price sensitivity among mobile service customers. Journal of Product and Brand Management 14(1): 65-73. https://doi.org/10.1108/10610420510583761.

Noor HM, Na'asah N, Jurry F. 2014. Determinants of customer satisfaction of service quality: City bus service in kota Kinabalu, Malaysia. Procedia - Social and Behavioral Sciences 153(March 2016): 595-605. https://doi.org/10.1016/j. sbspro.2014.10.092.

O'Loughlin C, Germà C. 2002. Application of the European customer satisfaction index to postal services. Structural equation models versus partial least squares. Dialnet.Unirioja.Es.

Parasuraman, Valarie Z, Leonard LB. 1988. SERQUAL: A Multiple-Item scale for measuring consumer perceptions of service quality. Journal of Retailing.

Pham A et al. 2017. Privateride: A privacy-enhanced ride-hailing service. Proceedings on Privacy Enhancing Technologies 2017(2): 38-56. https:// doi.org/10.1515/popets-2017-0015.

Poliakov A. 2010. Application of the customers satisfaction index to transport services. V(Iv): 208-15.

Prabowo Y. 2018. Uber, Go-Jek, Grab: What do people in Indonesia actually want from ride-hailing apps? EcommerceIQ. https://ecommerceiq.asia/ cp-ride-hailing-apps-in-indonesia/ [April 6, 2020].

Rahhal W. 2015. The effects of service quality dimensions on customer satisfaction: An empirical investigation in syrian mobile telecommunication services. International Journal of Business and Management Invention ISSN (Online 4(5): 2319-8028.

Rida Khurshid et al. 2012. Service quality and customer satisfaction in public transport sector of Pakistan: An empirical study. International Journal of Economics and Management Sciences 1(9): 24-30.

Saunders M, Philip L, Adrian T. 2009. Pearson Education, UK. Research methods for business students. Fitfth Edition.

Serajuddin U, Nada H. 2020. New world bank country classification by income level: 2020 - 2021. Worldbankblogs. https://blogs.worldbank. org/opendata/new-world-bank-countryclassifications-income-level-2020-2021 [Juli 1, 2020].

Siddiqi Z, Ron B. 2013. Dynamic ridesharing and information and communications technology: past, present and future prospects. Journal Transportation Planning and Technology 36(6): 479-98. https://doi.org/10.1080/03081060.2013 .830895 .

Suhami et al. 2018. Service attributes, customer 
satisfaction and return usage: A case of Uber Malaysia. Journal of Tourism, Hospitality \& Culinary Arts (JTHCA) 10(2): 81-103. https:// fhtm.uitm.edu.my/images/jthca/Vol10Issue2/ Chap-7.pdf.

Suharto S, Sulistiyono S. 2015. The relationship of service quality on consumer satisfaction in shipyard industry. Modern Applied Science 9(11): 247. https://doi.org/10.5539/mas.v9n11p247.
Tam JLM. 2004. Customer satisfaction, service quality andperceivedvalue:Anintegrativemodel.Journal of Marketing Management 20 (7-8): 897-917. https://doi.org/10.1362/0267257041838719.

Uyoga D. 2018. Relationship between Customer Responsiveness, Service Performance and Satisfaction among Airline Passengers in Kenya. Journal of Emerging Trends in Economics and Management Sciences (JETEMS) 10(2): 1-15. 